УДК 616.9(471.44)+(574.1)

\title{
А.К.Гражданов ${ }^{1}$, О.И.Кожанова ${ }^{2}$, А.В.Топорков ${ }^{1}$, Т.З.Аязбаев ${ }^{3}$, Н.И.Матвеева ${ }^{2}$, И.Г.Карнаухов ${ }^{1}$,
} Н.В.Попов ${ }^{1}$, А.С.Раздорский ${ }^{1}$, Г.Н.Архипова ${ }^{2}$

\section{СРАВНИТЕЛЬНЫЙ АНАЛИЗ ПРОЯВЛЕНИЙ ОПАСНЫХ ИНФЕКЦИЙ В САРАТОВСКОЙ И ЗАПАДНО-КАЗАХСТАНСКОЙ ОБЛАСТЯХ В ЦЕЛЯХ СОВРЕМЕННОЙ ОЦЕНКИ ЭПИДЕМИОЛОГИЧЕСКИХ РИСКОВ}

\author{
${ }^{1}$ ФКУЗ «Российский научно-исследовательский противочумный институт «Микроб», Саратов, Российская

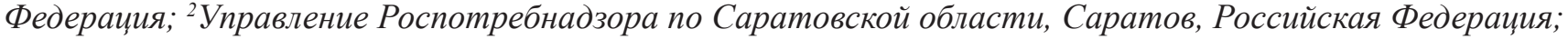 \\ ${ }^{3}$ Уральская противочумная станция Комитета Госсанэпиднадзора Минздрава Республики Казахстан, \\ Уральск, Республика Казахстан
}

На примере Саратовской и Западно-Казахстанской областей проведен анализ современной эпидемиологической и эпизоотологической ситуации в приграничных регионах двух государств: Российской Федерации и Республики Казахстан. Показано общее пространство природно-очаговых территорий не только давно существующих здесь инфекций, таких как туляремия, но интенсивное распространение и формирование природных очагов новых инфекционных болезней: Крымской геморрагической лихорадки и лихорадки Западного Нила. Особую актуальность данное явление приобретает в связи с тем, что распространение ранее неизвестных в этих местах инфекций происходит одновременно на смежных территориях двух областей. Выявленная однотипность эпидемиологических рисков для населения в соседних регионах обусловливает необходимость выработки единой системы предупреждения чрезвычайных ситуаций санитарно-эпидемиологического характера на территориях обеих областей.

Ключевые слова: чума, туляремия, холера, бруцеллез, сибирская язва, бешенство, геморрагические лихорадки, природный очаг, эпидемиологические риски, профилактика.

\section{A.K.Grazhdanov ${ }^{1}$, O.I.Kozhanova ${ }^{2}$, A.V.Toporkov ${ }^{1}$, T.Z.Ayazbaev ${ }^{3}$, N.I.Matveeva ${ }^{2}$, I.G.Karnaukhov ${ }^{1}$, N.V.Popov ${ }^{1}$, A.S.Razdorsky ${ }^{1}$, G.N.Arkhipova ${ }^{2}$ \\ Comparative Analysis of Particularly Dangerous Infections Manifestations in the Territory of the Saratov and West-Kazakhstan Regions with a View to Advanced Epidemiological Risk Assessment}

\begin{abstract}
${ }^{1}$ Russian Research Anti-Plague Institute "Microbe”, Saratov, Russian Federation; ${ }^{2}$ Rospotrebnadzor Administration in the Saratov Region, Saratov, Russian Federation; ${ }^{3}$ Uralsk Plague Control Station of the Committee for Sanitary and Epidemiological Surveillance, Ministry of Health in the Republic of Kazakhstan, Uralsk, Republic of Kazakhstan

On the model of the Saratov and West-Kazakhstan regions carried out is the analysis of the current epidemiological and epizootiological situations in the cross-border territories of the two states: the Russian Federation and the Republic of Kazakhstan. Depicted is not only the common area of natural-focal territories of old-established infections, such as tularemia, but an intense outspread and formation of natural foci of the emerging infectious diseases too: Crimean hemorrhagic and West Nile fevers. This phenomenon assumes a great deal of importance due to dissemination and circulation of previously unknown to these areas infections concurrently in the two neighboring regions. Specified uniformity of epidemiological public risks in the bordering regions testifies to the need for development and implementation of the integrated system for prevention and response to the emergency situations in the sphere of sanitary-epidemiological welfare of the population in the territory of both of them.
\end{abstract}

Key words: plague, tularemia, cholera, brucellosis, anthrax, rabies, hemorrhagic fevers, natural focus, epidemiological risks, prophylaxis.

В рамках развивающихся двусторонних отношений Российской Федерации и Республики Казахстан в области обеспечения санитарноэпидемиологического благополучия населения успешно функционирует приграничное сотрудничество Саратовской и Западно-Казахстанской областей (ЗКО). Имея общую границу протяженностью 568,3 км и занимая смежную территорию, области имеют много сходных и отличительных природноклиматических характеристик. Саратовская область занимает площадь 101240 км $^{2}$ и располагается в лесостепной, степной и полупустынной природных зонах, а ЗКО находится южнее - в степной, полупустынной и пустынной зонах и занимает 151339 км² $^{2}$. С целью дальнейшего развития регионального партнерства санитарно-эпидемиологических служб двух областей в сфере эпидемиологического надзора и санитарной охраны территории необходим систематический обмен информацией и обсуждение современных проявлений инфекционной заболеваемости. Рассмотрим эпидемиологическую и эпизоотологическую ситуацию по опасным инфекциям, представляющим реальную (потенциальную) угрозу санитарноэпидемиологическому благополучию населения, 
эпидемические проявления которых приравнены к чрезвычайной ситуации. Это важно для определения совместных действий по сохранению общего эпидемиологического благополучия.

Чума. В Саратовской области природные очаги чумы не выявлены. Но на границе с южной оконечностью Саратовского Заволжья располагается северная окраина Волго-Уральского степного очага чумы. На соседней территории Казахстана в непосредственной близости от Александрово-Гайского и Новоузенского районов в начале XX в. имели место эпизоотии чумы среди малых сусликов, которые неоднократно вызывали эпидемические вспышки чумы среди людей. Последний раз чума проявила себя здесь в виде эпизоотий в 1931 г. С того времени и до сегодняшнего дня (80 лет) эпизоотии чумы на этой территории не регистрируются несмотря на систематическое обследование.

В ЗКО природная очаговость чумы установлена в 1913 г. Здесь расположены три природных очага чумы: Волго-Уральский песчаный, Волго-Уральский степной и Зауральский (Урало-Уильский) степной, которые занимают $75 \%$ общей площади области. Все три природных очага относятся к эпидемически высокоактивным. Это положение ярко иллюстрируют сведения из недавней истории: только в одной Западно-Казахстанской области зарегистрирована почти четвертая часть всех заболевших и умерших от чумы на территории бывшего СССР за вековой период. Критически высокая эпидемичность территории обусловлена частыми и острыми эпизоотиями чумы среди грызунов, высокой вирулентностью циркулирующих штаммов возбудителя чумы и особенностями быта и хозяйственной деятельности местного населения. В последующие десятилетия, благодаря активно проводимым профилактическим мероприятиям и коренному улучшению медицинского обеспечения, эпидемические вспышки чумы уже не регистрируются. В то же время эпизоотии чумы среди грызунов выявляются почти ежегодно. Так, за 100 лет наблюдения (1913-2012 гг.) эпизоотии чумы на территории ЗКО обнаруживались 78 лет. В силу чего постоянно сохраняются реальные эпидемиологические риски заражения человека, что выражается в спорадической заболеваемости. Последний случай заболевания чумой в Волго-Уральских песках отмечен в 1997 г. Ежегодно эпизоотологическому обследованию на чуму подвергается вся энзоотичная территория. В настоящее время в природных очагах чумы Западного Казахстана наступил межэпизоотический период. Средняя длительность межэпизоотического периода на этой территории составляет 3-4 года, максимум - 9 лет. Последние эпизоотии чумы здесь выявлены в 2007 г. В предшествующие годы (1971-2007 гг.) в пределах Жангалинского района, расположенного на севере Волго-Уральских песков, эпизоотии чумы регистрировались 37 лет подряд. В связи с благоприятными погодными условиями идет интенсивное восстановление численности носите- лей и переносчиков инфекции, что может привести к новой эпизоотической активизации очага. Учитывая эти обстоятельства, ситуацию в природных очагах чумы следует расценивать как неустойчивую. При возобновлении эпизоотий чумы возможны заболевания людей и занос опасной инфекции на соседние территории.

Отсутствие в последние годы заболеваний людей чумой не должно дезориентировать службы здравоохранения. Чума остается актуальной инфекцией, способной вызвать чрезвычайную ситуацию санитарно-эпидемиологического характера. Необходимо продолжать совместную работу по повышению эффективности эпидемиологического надзора, принимать адекватные меры для своевременного выявления больных чумой в природных очагах.

Туляремия. В Саратовской области природная очаговость туляремии установлена в 1931 г. Здесь выявлено несколько типов природных очагов: степной, пойменно-болотный, лесной. Доминирующее положение занимает степной тип. К настоящему времени эпизоотии туляремии зарегистрированы в 24 из 38 сельских районов и в зеленой зоне Саратова. В прошлом имели место частые и крупные эпидемические вспышки туляремии. Так, в период с 1931 по 1993 год всего по области зарегистрировано 50973 больных туляремией [16]. По условиям заражения людей отмечены три основных эпидемиологических типа: трансмиссивный, промысловый и сельскохозяйственный. После официального запрещения охоты на водяную полевку промысловый тип заражения перестал иметь преобладающее значение и число вспышек пошло на убыль. Главную роль в прекращении эпидемических вспышек туляремии сыграла массовая вакцинация населения, после проведения которой заболеваемость уже не превышала спорадический уровень. Природные очаги туляремии до сегодняшнего дня остаются эпизоотически активными. Последний случай заболевания туляремией среди жителей Саратовской области зарегистрирован в 2000 г. В 2007 г. имело место заражение туляремией жителя Москвы на территории Новоузенского района.

В ЗКО природная очаговость туляремии установлена в 1928 г. Здесь выделены природные очаги двух типов: степной и пойменно-болотный. Основные носители инфекции - водяная полевка и мелкие мышевидные грызуны, основные переносчики - иксодовые клещи. До 1960 г. регистрировались крупные эпидемические вспышки, которые сменялись единичными заболеваниями. За период с 1928 по 1960 год всего зарегистрировано 854 больных. Эпидемическая активность резко снизилась после начала массовой вакцинации населения против туляремии. За последние полвека в области выявлено всего три случая заболевания туляремией (1965, 2002, 2007 гг.). За период наблюдения эпизоотии туляремии обнаружены на территории всех 12 административных районов. В настоящее время эпизоотии туляремии регистрируются ежегодно. Эпизоотическая ситуация крайне 
обострилась в 2011-2012 гг., когда возбудитель туляремии, кроме грызунов и клещей, был выделен из воды небольшой реки и, впервые в Казахстане, от птицы - каменки-плясуньи. Появление новых эпидемиологических рисков заражения людей потребовало дополнительных мер профилактики. Еще одной особенностью современной туляремии является то, что исконные носители чумы - малые суслики и песчанки - стали принимать все более активное участие в эпизоотиях этой инфекции. Это привело к активизации и распространению туляремии на энзоотичные по чуме территории и формированию новых сочетанных природных очагов чумы и туляремии. На пограничных с Россией территориях наиболее высокая эпизоотическая активность отмечена в долинах рек Большого и Малого Узеней в пределах Казталовского района. Этот участок определен как территория с высоким уровнем риска заражения туляремией [6].

Таким образом, территории Саратовской и Западно-Казахстанской областей имеют близкие по типам природные очаги туляремии, эпизоотии в которых регистрируются почти ежегодно. В поймах рек Большой и Малый Узень сформировалась общая трансграничная природно-очаговая территория. Активизация проявлений туляремии в Саратовской области и ЗКО также происходит синхронно. Так, после длительного перерыва в 2007 г. почти одновременно в обеих областях произошло по одному случаю заражения людей туляремией. Принимая во внимание, что на сегодняшний день имеется испытанная временем высокоэффективная вакцина, эпидемиологические риски инфицирования туляремией людей на территории эпизоотий могут быть сведены к нулю.

Холера. В Саратовской области все эпидемии холеры имели заносной характер. Заносы холеры происходили чаще всего из городов Нижнего Поволжья (Астрахань, Волгоград). Если рассматривать период после 1923 г., то заболевания холерой в Саратовской области регистрировались в 1942 г. и в 1970-1976 гг. [8]. Первые больные холерой в 1942 г. прибыли из Сталинграда, где имела место эпидемическая вспышка холеры. Всего в Саратовской области в 1942 г. выявлено 210 больных холерой (в Саратове - 202). В период седьмой пандемии, когда эпидемические вспышки холеры охватили европейскую часть юго-востока России, заболевания холерой в Саратовской области были связаны с заносом инфекции из Астрахани (1970-1976 гг.). Всего диагностирован 131 больной холерой в основном в расположенных по берегам Волги городах: Саратове, Вольске, Балаково. Своевременно проведенные противоэпидемические мероприятия позволяли каждый раз быстро купировать инфекцию. В настоящее время в Саратовской области осуществляется систематический мониторинг холеры. В 2011 г. из объектов окружающей среды культуры холерных вибрионов O1 и О139 серогрупп не выделены [7]. Токсигенный холерный вибрион из воды открытых водоемов не выделялся с 2001 г. Не выделен холерный вибрион и из клинического материала больных кишечной инфекцией. В результате лабораторных исследований воды открытых водоемов в 2011 г. в 12,8 \% проб выделены атоксигенные холерные вибрионы не О1 серогруппы.

В ЗКО известны только заносные случаи холеры. После 1923 г. заболевания холерой в области имели место во время войны - в сентябре 1942 г. Больные холерой обнаружены среди пассажиров двух пароходов, которые прибыли по реке Урал из Астрахани с эвакуируемыми людьми. Пароходы были остановлены в поселке Калмыково, здесь организовали госпиталь. По официальным данным, в Калмыково зарегистрировано 19 больных холерой. Установлено, что первые заболевания связаны с пребыванием пассажиров в Астрахани, где была вспышка холеры. Уже после Астраханской эпидемии холеры в 1970 г. в Уральске в восьми случаях выявляли вибрионосителей холеры среди здоровых работников речного порта, совершающих рейсы по реке Урал от Уральска до Гурьева (1970, 1972, 1974 гг.). Все последующие годы в области продолжается постоянный мониторинг проявлений холеры. В сентябре 2005 г. в Уральске зарегистрировано два случая выделения холерных вибрионов О1 биовара Эльтор серовара Инаба от двух женщин, прибывших из Южно-Казахстанской области. Эти женщины (мать и дочь) находились на отдыхе в санатории, где мать заболела, у нее был частый жидкий стул. По прибытии в Уральск больная госпитализирована в инфекционный стационар. Дочь оставалась здоровой, каких-либо клинических проявлений кишечной инфекции не наблюдалось. Оба штамма холерного вибриона, выделенных от больной и контактной, были гемолизотрицательные и обладали холерогенностью. Холерогенность (токсигенность) культур изучали на кроликах-сосунках и в ПЦР. По совокупности данных эти два случая выделения токсигенных штаммов холерных вибрионов определены как завозные. В 2010 г. от семи больных острыми кишечными инфекциями, двух пациентов психоневрологического диспансера и двух контактных по семейному очагу выделены культуры холерного вибриона не О1 серогруппы, по результатам молекулярно-генетического исследования - нетоксигенные. В 2011 г. от одного больного ОКИ и двух пациентов психоневрологического диспансера выделено три штамма холерного вибриона не О1 серогруппы, нетоксигенные. Летом этого же года из воды пруда в Казталовском районе выделено четыре штамма холерных вибрионов О1 серогруппы биовара Эльтор серовара Инаба, все нетоксигенные. В ПЦР выявлена ДНК холерного вибриона и антиген О1. Редкие случаи однократного выделения таких холерных вибрионов из воды небольшого искусственного водоема, расположенного в «глухой» степи, пока не поддаются удовлетворительному объяснению. Обсемененность проб воды открытых 
водоемов холерными вибрионами не O1 серогруппы в ЗКО составляет в среднем $50 \%$.

Территории Саратовской и Западно-Казахстанской областей равнозначны по проявлениям холеры. Здесь возможны только заносные случаи заболеваний холерой, так как нет природных и социальных условий для укоренения этой инфекции. Учитывая неблагоприятный мировой прогноз, необходимо выполнение всех мероприятий эпиднадзора по холере, а взаимодействие двух областей даст более эффективные результаты, тем более что опыт сотрудничества в этой области был приобретен еще в период эпидемии холеры в СССР в 1970 г., когда для оказания помощи в проведении массовых диагностических исследований в Саратове была привлечена специализированная противоэпидемическая бригада (СПЭБ) Уральской противочумной станции.

Бруцеллез. В Саратовской области в период 2000-2009 гг. выявлено 77 больных бруцеллезом [9]. В последние годы случаи бруцеллеза у людей не регистрируются. Несмотря на достигнутые успехи в профилактике этого заболевания эпизоотологическая ситуация по бруцеллезу среди сельскохозяйственных животных остается неблагополучной. Ежегодно выявляют эпизоотические очаги среди крупного рогатого скота в хозяйствах частного и общественного секторов.

ЗКО стабильно неблагополучна по бруцеллезу людей и сельскохозяйственных животных. В период с 2000 по 2009 год диагностировано 373 больных бруцеллезом. В 2010 г. выявлен 61 больной первичным бруцеллезом. Диагноз подтвержден выделением возбудителя в 70,3 \% случаев. Все выделенные культуры изучены и идентифицированы как Brucella melitensis. В 2011 г. в области установлено 55 заболеваний людей бруцеллезом (Акжаикский район - 14, Бокейординский -1 , Бурлинский -3 , Жанибекский - 3, Зеленовский - 2, Казталовский - 4, Каратобинский - 2, Сырымский - 14, Теректинский 1, Чингирлауский - 9, Уральск - 2), у 90 \% больных выделен возбудитель. В 2011 г., впервые за последние 20 лет, от одного больного изолирован штамм Brucella abortus, 1 биотип. Источником инфекции во всех случаях послужили больные домашние животные из индивидуальных хозяйств. В 2011 г. проводилось оздоровление по бруцеллезу среди крупного рогатого скота четырех населенных пунктов.

В связи с общим увеличением численности домашнего скота, наличием неблагополучных по бруцеллезу хозяйств остаются высокими эпидемиологические риски заболевания людей. Для предупреждения заражения людей следует совместно с ветеринарной службой направить основные усилия на своевременное выявление бруцеллезных очагов и проведение мероприятий по их локализации и ликвидации. В связи с образованием единого таможенного пространства между Россией и Казахстаном с обеих сторон требуется более жесткий контроль над трансграничным перемещением домашнего скота.
Необходимо определить порядок такого контроля в рамках Таможенного союза.

Сибирская язва. Саратовская область энзоотична по сибирской язве. По официальным данным, на территории всех районов области существует более 3000 стационарно неблагополучных пунктов [1]. Наличие множества почвенных очагов сибирской язвы в местах выпаса скота создает реальную угрозу заражения травоядных животных, что при определенных условиях может привести к заболеванию людей. В 2011 г. случаев заболевания людей и животных сибирской язвой в области не зарегистрировано.

ЗКО также энзоотична по сибирской язве. Здесь имеется 157 стационарно неблагополучных пунктов, которые располагаются во всех районах области [14]. Заболевания людей возникают периодически на фоне эпизоотий среди сельскохозяйственных животных и всегда связаны с нарушением ветеринарносанитарных правил. В августе 2011 г. в поселке Таловка Жанибекского района два человека заболели сибирской язвой. Оба участвовали в вынужденном забое теленка. Обоим поставлен диагноз - кожная форма сибирской язвы. Диагноз подтвержден обнаружением ДНК возбудителя сибирской язвы у одного больного. От забитого животного и из пробы почвы с места забоя изолирован возбудитель сибирской язвы. Результаты лабораторных исследований позволили установить источник заражения людей, пути передачи инфекции и, в конечном итоге, своевременно провести мероприятия по локализации и ликвидации очага сибирской язвы. На сегодняшний день на территории ЗКО имеются четыре активных стационарно неблагополучных пункта с высоким риском инфицирования возбудителем сибирской язвы.

В Российской Федерации и Республике Казахстан составлены и опубликованы Кадастры стационарно неблагополучных по сибирской язве пунктов. Эти документы служат основой для планирования профилактических мероприятий, центральное место в которых принадлежит вакцинации сельскохозяйственных животных. Необходимо постоянно обновлять существующую базу данных за счет еще неучтенных неблагополучных пунктов. Анализ материалов показал, что главной причиной продолжающихся эпизоотий и эпидемических проявлений сибирской язвы в каждом отдельном случае является нарушение ветеринарно-санитарных правил. Именно в этом кроются современные эпидемиологические риски заражения сибирской язвой местного населения. Только предупреждение нарушений ветеринарносанитарных правил может сохранять эпидемиологическое благополучие на территориях, потенциально опасных по этой инфекции.

Геморрагическая лихорадка с почечным синдромом (ГЛПС). В Саратовской области природная очаговость ГЛПС установлена в 1964 г. [10]. На сегодня эпизоотии ГЛПС выявлены на территории 30 районов и в зеленой зоне Саратова. По официальным данным, за весь период наблюдения (1964-2011гг.) 
в области зарегистрировано 6283 больных этой лихорадкой, из них 31 умер [1]. Уровень заболеваемости людей ГЛПС в Саратовской области выше, чем в среднем по России. Подъемы заболеваемости отмечаются каждые 5-6 лет и связаны с увеличением численности рыжей полевки - основного носителя вируса. Наиболее высокий уровень заболеваемости зарегистрирован в 1986 г., когда было выявлено 2349 больных ГЛПС. В последние годы эпидемиологическая ситуация по этой инфекции стабилизировалась. В 2011 г. в городах и районах области отмечено 37 случаев ГЛПС. Показатель заболеваемости на 100 тыс. населения составил 1,44 . Для области характерны лесной и бытовой типы заражения людей. Чаще всего больные поступали в осенне-зимние месяцы, преобладали тяжелые и средней тяжести клинические формы. Эпизоотологические прогнозы составляют по результатам ежегодно проводимого обследования территории природных очагов. На наиболее опасных участках проводится поселковая и барьерная дератизация.

В ЗКО впервые больные ГЛПС были диагностированы в 2000 г., а в 2001 г. установлена природная очаговость этой инфекции [2]. Дальнейшие исследования позволили очертить ареал распространения и определить круг носителей хантавируса. Эпидемические вспышки ГЛПС приурочены к долине реки Урал, где обитает рыжая полевка. В годы высокой численности рыжей полевки наблюдаются заболевания людей. В период с 2000 по 2010 год заболевания отмечались ежегодно, за исключением 2002 г. Всего зарегистрировано и лабораторно подтверждено 194 случая ГЛПС, один закончился летально. Заболеваемость по годам была неравномерной, наибольшая отмечена в 2005 г. Чаще всего регистрировались тяжелые и средней степени тяжести клинические формы заболевания. Установлена этиологическая роль хантавируса серотипа Пуумала, который обнаружен у грызунов и людей. Заболеваемость ГЛПС носит ярко выраженный сезонный характер. Самое большое число больных выявляли в ноябре. Наиболее часто реализуется лесной тип заражения людей. В 2011 г. было выявлено шесть больных ГЛПС. Все они отмечали пребывание на территории эпизоотий. Профилактические мероприятия направлены на ограничение возможных контактов людей с грызунами. По эпидпоказаниям проводится поселковая дератизация.

Постоянно сохраняющиеся эпидемиологические риски в природных очагах приводят к ежегодной заболеваемости ГЛПС, что представляет определенную проблему для здравоохранения обеих областей. Дорогостоящие работы по снижению численности грызунов, являющихся источником инфекции, дают лишь кратковременный эффект. Кардинальным образом ситуацию по борьбе с ГЛПС может изменить лишь вакцинопрофилактика. Экспериментальные серии отечественной вакцины против геморрагической лихорадки с почечным синдромом уже имеют- ся, но лабораторные и полевые испытания до сих пор не завершены [15].

Бешенство. Саратовская область является территорией с высокой степенью риска заражения населения бешенством [9]. Природные очаги бешенства имеются во всех районах области, случаи бешенства у животных регистрируются ежегодно. Превалирует бешенство у лис. В последние годы отмечается активное вовлечение в эпизоотии бешенства домашних животных (собак и кошек). Ситуация усугубляется ростом числа безнадзорных собак и кошек, отсутствием регламентирующих документов по правилам содержания домашних животных [17]. За счет одичавших собак происходит перенос инфекции из природных в антропоургические очаги. Постоянно увеличивается число пострадавших от укусов бродячими собаками. Остается высокой обращаемость населения за медицинской помощью по поводу повреждений, нанесенных животными, с назначением антирабической вакцинации. В 2011 г. заболевания бешенством среди людей в Саратовской области не зарегистрированы.

Вся территория ЗКО энзоотична по бешенству. Заболевания бешенством систематически регистрируются среди домашних и диких животных: коров, овец, лошадей, собак, кошек, волков и лисиц. На этом фоне спорадически возникают заболевания людей. В последние годы участились случаи нападения на людей волков, что связано с резким увеличением численности этих хищников на территории области. В 2011 г. один случай заболевания человека бешенством с летальным исходом имел место в пос. Жанибек. Источником инфекции послужила собственная собака. Этот больной по поводу укуса собаки за медицинской помощью не обращался. Для профилактики бешенства в области постоянно проводится отлов бродячих собак, а также внедряется вакцинация собак и кошек.

В целях снижения эпидемиологических рисков заражения бешенством в Саратовской и ЗападноКазахстанской областях целесообразно проводить пероральную вакцинацию не только домашних, но и диких плотоядных животных в природных условиях. Необходимо осуществлять регулирование численности диких животных для уменьшения активности природных очагов, а также повсеместно сокращать количество бродячих собак в населенных пунктах. Чрезвычайно важно введение на законодательной основе правил содержания домашних животных, peгламентирующих и меры ответственности владельцев за их нарушение.

Лихорадка Западного Нила (ЛЗН). В Саратовской области первый больной лихорадкой Западного Нила выявлен в 2010 г., в эпиданамнезе этого больного отмечалось посещение в летний период островов на р. Волга, где он был покусан комарами [11]. В летне-осенний период 2012 г. только до середины сентября лихорадка Западного Нила диагностирована у четырех больных. На территории 
области установлена циркуляция вируса Западного Нила среди мелких млекопитающих, птиц и клещей $[13,19,21]$. Специальными исследованиями обнаружена иммунная прослойка к этой инфекции у местного населения $[18,20]$. Эти эпидемиологические и эпизоотологические факторы свидетельствуют о формирования здесь природного очага ЛЗН.

В ЗКО впервые наличие специфических антител к лихорадке Западного Нила у людей установлено в 2010 г. [5]. В 2011 г. методом ПЦР обнаружена РНК вируса Западного Нила в восьми пробах четырех видов комаров, выловленных на территории Жанибекского и Бокейординского районов. Повторные исследования подтвердили наличие специфических антител к возбудителю ЛЗН у части населения Жанибекского района.

Мы являемся свидетелями уникального естественного явления: на смежных территориях Саратовской и Западно-Казахстанской областей вдоль пролетных трасс мигрирующих птиц формируется новый природный очаг лихорадки Западного Нила. Учитывая способность этой опасной инфекции к быстрому распространению, необходимо продолжить совместную обследовательскую и профилактическую работу в целях обозначения границы очага, степени его устойчивости и определения основных эпидемиологических рисков заражения людей.

Крымская геморрагическая лихорадка (КГЛ). В Саратовской области больные Крымской геморрагической лихорадкой не зарегистрированы. Но в последние годы получены сведения, указывающие на циркуляцию вируса Крымской-Конго геморрагической лихорадки (ККГЛ) среди грызунов и клещей $[19,21]$. У части обследованных людей и сельскохозяйственных животных выявлены специфические антитела к вирусу ККГЛ [20]. Эти данные свидетельствуют о наличии на территории области потенциальных возможностей становления природной очаговости КГЛ. Необходимо продолжить исследования.
В ЗКО циркуляция вируса ККГЛ среди крупного рогатого скота впервые обнаружена в 2007 г. [4]. В дальнейшем на территории Жанибекского и Бокейординского районов установлена высокая численность основных переносчиков этой инфекции клещей Hyalomma marginatum, зараженных вирусом ККГЛ. Антиген этого вируса выявлен у малых сусликов и обитающих здесь птиц. У местного населения обнаружены специфические антитела к вирусу ККГЛ. На сегодняшний день в ЗКО имеются все экологические условия для укоренения инфекции в местных биоценозах. Заболевания КГЛ в области не выявлены.

В современный период в Саратовской и ЗападноКазахстанской областях, наряду с ЛЗН, идет процесс активной циркуляции и распространения на новые территории вируса ККГЛ, что представляет потенциальную эпидемическую опасность для людей (рисунок). Эти обстоятельства требуют опережающих мер контроля и противодействия.

Клещевой боррелиоз (КБ). В Саратовской области в 2011 г. впервые зарегистрированы три случая заболевания клещевым боррелиозом. Эпидрасследование показало, что один человек заразился КБ в местных условиях, два других случая завозные. В первом полугодии 2012 г. выявлены еще два больных клещевым боррелиозом. На территории области установлена природная очаговость КБ, обнаружены специфические переносчики возбудителя болезни - клещи рода Ixodes, численность которых ежегодно возрастает [12]. Продолжается работа по оценке потенциала новой для территории природноочаговой инфекции.

В ЗКО в 2011 г. также впервые зарегистрирован случай клещевого боррелиоза. Согласно эпиданамнезу больная накануне заболевания была покусана клещами при посещении леса в Пензенской области России, где и произошло заражение. Диагноз клеще-

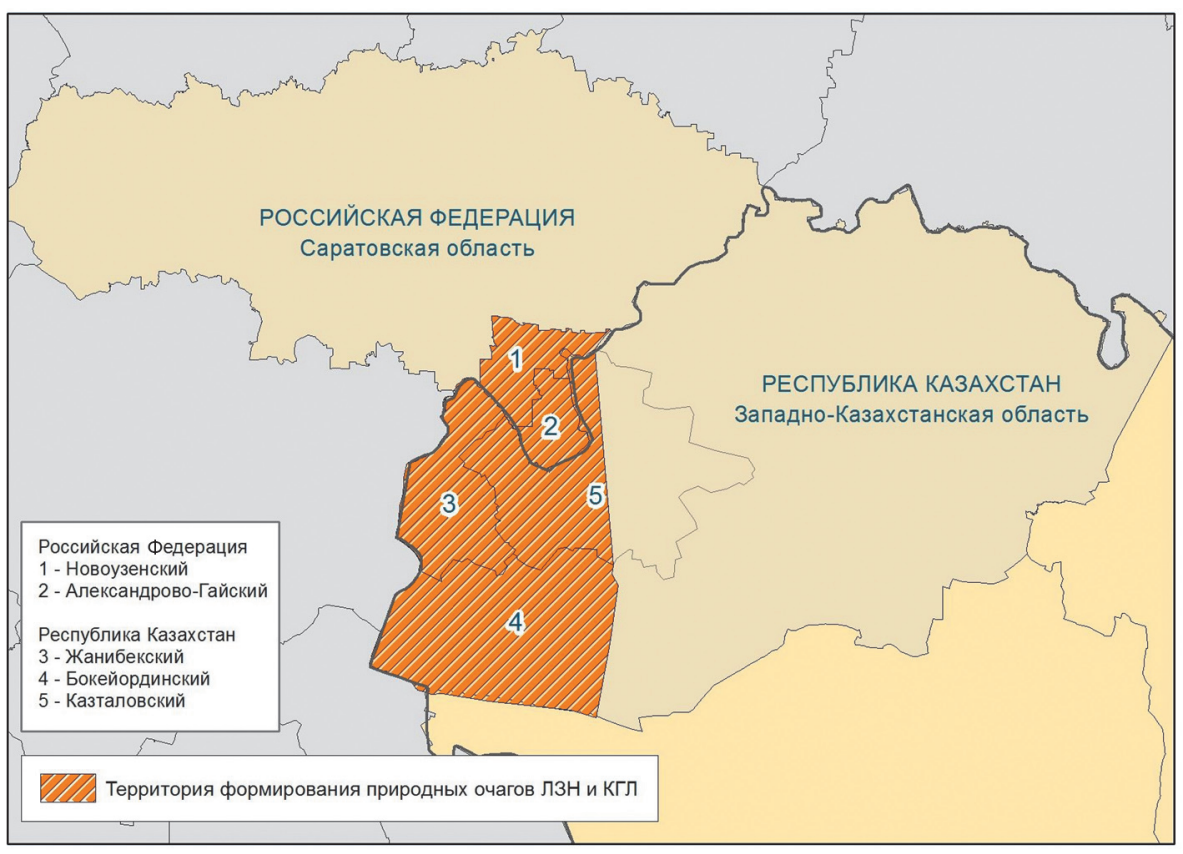

Единое эпизоотологическое пространство приграничных территорий Саратовской и Западно-Казахстанской областей, где формируются природные очаги ЛЗН и КГЛ 
вого боррелиоза подтвержден лабораторными исследованиями. После лечения пациентка выписана в удовлетворительном состоянии. Это первый опыт диагностики и ведения таких больных в Казахстане. В настоящее время проводится эпизоотологическое обследование территории области на КБ, организован лабораторный мониторинг этой инфекции.

Пастереллез. В ЗКО имело место природное явление, которое можно прировнять к стихийному бедствию. Дважды, в мае 2010 г. и 2011 г., на территории Жанибекского района зарегистрирован массовый падеж сайги. Только в 2010 г. в течение двух недель погибло более 12 тыс. этих антилоп. Скопившиеся для окота животные были сконцентрированы на небольшой территории. Гибли в основном недавно родившие самки и их детеныши. Безусловно, эту часть стада животных можно отнести к «группе риска». От павших сайгаков был выделен возбудитель пастереллеза (Pasteurella multocida). Окончательно причина массовой гибели сайгаков на западе Казахстана до сих пор не установлена, но основной версией падежа диких животных остается эпизоотия пастереллеза. Территория области энзоотична по этой инфекции. В разные годы от мелких млекопитающих и сельскохозяйственных животных выделяли возбудитель пастереллеза. Был случай заболевания пастереллезом человека с летальным исходом. Следовательно, пастереллезная инфекция устойчиво сохраняется среди диких и домашних животных и при определенных условиях может вызвать эпизоотию среди сайгаков.

Другие новые в краевой патологии природноочаговые инфекции. В Саратовской области в последние годы получены достоверные сведения о циркуляции вируса клещевого энцефалита среди мелких млекопитающих, клещей, птиц и людей [20, 21]. В ЗКО впервые в 2011 г. методом ПЦР выявлена зараженность вирусом клещевого энцефалита иксодовых клещей, получены данные о циркуляции этой инфекции среди населения. В 2004 г. впервые в ЗКО обнаружена спонтанная зараженность клещей Rhipicephalus pumilio возбудителем астраханской пятнистой лихорадки [3]. Установлена высокая численность этих клещей. В настоящее время продолжаются исследования с целью обозначить границы ареала возбудителя и возможности укоренения природного очага.

Таким образом, Саратовская и Западно-Казахстанская области имеют по ряду опасных инфекций единое эпизоотологическое и эпидемиологическое пространство, что подтверждается одновременным их проявлением (туляремия, заносы холеры). В современный период общая ситуация осложняется формированием на этих территориях новых сочетанных природных очагов опасных инфекционных заболеваний. Тесные экономические и культурные связи двух областей обусловливают проведение адекватных мероприятий по санитарной охране территорий. В 2011 г. подписано Соглашение о сотрудничестве для реализации мероприятий по са- нитарной охране территорий между Управлением Федеральной службы по надзору в сфере защиты прав потребителей и благополучия человека по Саратовской области и Департаментом Комитета государственного санитарно-эпидемиологического надзора Министерства здравоохранения Республики Казахстан по Западно-Казахстанской области. В условиях Таможенного союза необходимы унифицированные и более совершенные организационные формы сотрудничества в целях снижения эпидемиологических рисков, чтобы не только осуществлять эффективный надзор, но и взаимно гарантировать санитарно-эпидемиологическое благополучие на приграничной территории.

\section{СПИСОК ЛИТЕРАТУРЫ}

1. Государственный доклад «О санитарно-эпидемиологической обстановке в Саратовской области в 2011 году». Саратов; $2012.387 \mathrm{c}$.

2. Бидашко Ф.Г., Гражданов А.К., Рахманкулов Р.Р., Пак М.В., Белоножкина Л.Б., Андрющенко В.В., Токтаров М.И., Кдырсих Б.Г. Некоторые аспекты эпизоотологии УралоИлекского очага геморрагической лихорадки с почечным синдромом. Карантинные и зоонозные инфекиии в Казахстане. 2004; 2(10):96-104.

3. Гражданов А.К., Бидашко Ф.Г., Танитовский В.А., Смирнова С.Е., Карань Л.С., Платонов А.Е., Коротина Н.А. Астраханская риккетсиозная пятнистая лихорадка - новый потенциальный зооноз на западе Казахстана. Карантинные и зоонозные инфекции в Казахстане. 2005; 1-2 (11-12):17-20.

4. Гражданов А.К., Танитовский В.А., Белоножкина Л.Б., Бидашко Ф.Г., Смирнова С.Е., Захаров А.В., Андрющенко А.В. $\mathrm{O}$ новой природно-очаговой территории Крымской-Конго геморрагической лихорадки на западе Казахстана. Карантиннье $u$ зоонозные инфекичи в Казахстане. 2009; 1-2(19-20): 33-7.

5. Гражданов А.К., Аязбаев Т.З., Белоножкина Л.Б., Захаров А.В., Бидашко Ф.Г., Андрющенко А.В. Первые сведения о проявлении в Казахстане лихорадки Западного Нила. Карантинные и зоонозные инфекиии в Казахстане. 2011; 1-2(23-24):58-61.

6. Избанова У.А., Куница Т.Н., Гражданов А.К., Лухнова Л.Ю., Мека-Меченко Т.В., Пак М.В., Бидашко Ф.Г., Пазылов Е.К. Очаги туляремии как источники угрозы заражения людей на территории Западно-Казахстанской области Республики Казахстан. Дезинфекиия. Антисептика. 2012; 2(10):28-33.

7. Кожанова О.И., Фролова Л.Н. Проведение эпидемиологического надзора за холерой на территории Саратовской области. Инфекиия и иммунитет. 2012; 2(1-2):157.

8. Кологоров А.И., Кедрова О.В., Васенин А.С., Кокушкин А.М., Малыхина 3.В. Закономерности заноса и характера распространения эпидемических проявлений холеры в Саратовской области. В кн.: Природно-очаговые инфекции в Нижнем Поволжье. Волгоград; 2000. С. 116-23.

9. Кологоров А.И., Дмитриева Л.Н., Шиянова А.Е., Тарасов М.А., Поршаков А.М., Попов Н.В., Топорков В.П., Топорков А.В., Кутырев В.В. Эпидемиологическая ситуация по природноочаговым и зоонозным инфекциям в Приволжском Федеральном округе в 2000-2009 гг. и прогноз на 2010 г. Пробл. особо оnacнblx инф. 2010; 2(104):5-10.

10. Коротков В.Б., Наумов А.В., Самойлова Л.В. Геморрагическая лихорадка с почечным синдромом в Саратовской области (эпидемиологические аспекты). Саратов; 1996. 128 с.

11. Красовская Т.Ю., Щербакова С.А., Шарова И.Н., Найденова Е.В., Билько Е.А., Чекашов В.Н., Матросов А.Н., Яковлев С.А., Поршаков А.М., Шилов М.M., Рябова А.В., Князева Т.В., Мокроусова Т.В., Федорова 3.П., Кресова У.А., Талаева Е.А., Миронова Н.И., Кутырев В.В. Изучение циркуляции вируса Западного Нила на территории Саратовской области в 2010 г. Пробл. особо опасных инф. 2011; 3(109):13-7.

12. Кресова У.А., Казакова Л.В., Гаранина С.Б., Кожанова О.И. Актуальные клещевые инфекции Саратовской области. Инфекиия и иммунитет. 2012; 2 (1-2):160.

13. Кутырев И.В., Билько Е.А., Шарова И.Н., Красовская Т.Ю., Чекашов В.Н., Матросов А.Н. Оценка роли фоновых видов мышевидных грызунов в сохранении возбудителей арбовирусных инфекций в полупустынной зоне Саратовского Заволжья. Пробл. особо опасных инф. 2008; 3(97):19-22.

14. Лухнова Л.Ю., Айкимбаев А.М., Пазылов Е.К., Гражданов А.К., Соломадин М.В., Иманкул С.И., Мека-Меченко Т.В., Некрасова Л.Е. Эпидемиологическая и эпизоотологическая 
ситуация по сибирской язве на территории Западно-Казахстанской области. Дезинфекиия. Антисептика. 2012; 1(9):31-5.

15. Ткаченко Е.А., Дзагурова Т.К., Набатников П.А Коротина Н.А., Шевелев А.Б., Соцкова С.Е., Малкин А.Е., Киктенко А.В., Воробьева М.С., Михайлов М.И.' Разработка вакцины против геморрагической лихорадки с почечным синдромом. Инфекиия и иммунитет. 2012; 2(1-2):202.

16. Федорова З.П., Коротков В.Б., Агафонова Т.К., Барабанова А.В. О заболеваемости туляремией в Саратовской области и современном состоянии природных очагов. Пробл. особо опасныхх инф. 1993; 1-2:163-6.

17. Федорова 3.П., Кожанова О.И., Красильникова Н.Н. Актуальные вопросы снижения уровня обращаемости населения за медицинской помощью по поводу укусов животными Инфекиия и иммунитет. 2012; 2(1-2):206.

18. Щербакова С.А., Головинская О.Н., Клюева Е.В., Гаранина С.Б., Савицкая Л.В., Куличенко А.Н., Кутырев В.В. Результаты исследования сывороток крови населения Саратова на антитела к арбовирусам. Bonp. вирусол. 2002; 3:32-4.

19. Щербакова С.А., Билько Е.А., Клюева Е.В., Данилов А.Н., Плотникова Е.А., Тарасов М.А., Чекашов В.Н.,, Удовиков А.И., Князева Т.В., Шилов М.М., Самойлова Л.В., Храмов В.Н., Казакова Л.В., Куклев Е.В., Куличенко А.Н. Экология распространения арбовирусов на территории Саратовской области. Журн. микробиол., эпидемиол. и иммунобиол. 2005; 5:27-30.

20. Щербакова С.А., Билько Е.А., Найденова Е.В., Красовская Т.Ю., Шарова И.Н., Пионтковский С.А., Уткин Д.В., Чекашов В.Н.,Слудский А.А., Попов Н.В., Куклев Е.В., Фирстов Е.Н., Потемина Л.П., Логунова Т.Е., Водина Е.А., Куличенко А.Н., Кутырев В.В. Экологические и эпидемиологические аспекты циркуляции арбовирусов на территории Саратовской области. В кн.: Арбовирусы и арбовирусные инфекции. М.; 2007. С. 150-2.

21. Щербакова С.А., Билько Е.А., Найденова Е.В., Кутырев И.В., Красовская Т.Ю., Слудский А.А., Князева Т.В., Матросов А.Н., Чекашов В.Н., Шарова И.Н., Самойлова Л.В. Выявление антигенов арбовирусов в комарах и клещах, обитающих на территории Саратовской области. Мед. паразитол. и паразитарн. бол. 2009; 2:38-41.

\section{References}

1. State report on the "Sanitary-epidemiological situation in the Saratov region in 2011". Saratov; $2012.387 \mathrm{p}$

2. Bidashko F.G., Grazhdanov A.K., Rakhmankulov R.R., Pak M.V Belonozhkina L.B., Andryushchenko V.V., Toktarov M.I., Kdyrsikh B.G. [Certain aspects of epizootiology as concerns Ural-Ileksk focus of hemorrhagic fever with renal syndrome]. Karantin. Zoonoz. Infek. v Kazakhstane. 2004; 2(10):96-104.

3. Grazhdanov A.K., Bidashko F.G. Tanitovsky V.A., Smirnova S.E., Karan' L.S., Platonov A.E., Korotina N.A. [Astrakhan rickettsial spotted fever - novel potential zoonotic infection in the west of the Republic of ted fever - novel potential zoonotic infection in the west of the Republic of
Kazakhstan]. Karantin. Zoonoz. Infek. v Kazakhstane. 2005; 1-2(11-12):1720 .

4. Grazhdanov A.K., Tanitovsky V.A., Belonozhkina L.B., Bidashko F.G., Smirnova S.E., Zakharov A.V., Andryushchenko A.V. [Regarding a new natural-focal territory of Crimean-Congo hemorrhagic fever in the west of the Republic of Kazakhstan]. Karantin. Zoonoz. Infek. v Kazakhstane. 2009 $1-2(19-20): 33-7$.

5. Grazhdanov A.K. Ayazbaev T.Z., Belonozhkina L.B., Zakharov A.V., Bidashko F.G., Andryushchenko A.V. [First knowledge of onset of the West Nile fever in Kazakhstan]. Karantin. Zoonoz. Infek. v Kazakhstane. West Nile fever in Kazak

6. Izbanova U.A., Kunitsa T.N., Grazhdanov A.K., Lukhnova L.Yu., Meka-Mechenko T.V., Pak M.V., Bidashko F.G., Pazylov E.K. [Tularemia foci as a source of threat of population infection in the territory of the WestKazakhstan region of the Republic of Kazakhstan]. Dezinfektsiya. Antiseptika. 2012; 2(10):28-33.

7. Kozhanova O.I., Frolova L.N. [Epidemiological surveillance over cholera in the territory of the Saratov region]. Infektsiya i Immunitet. 2012; 2(1-2): 157 .

8. Kologorov A.I., Kedrova O.V., Vasenin A.S., Kokushkin A.M., Malykhina Z.V. [Regularities of import and distributional pattern of epidemiological cholera manifestations in the Saratov region]. In: [Natural-Foca Infections in the Lower Volga Region]. Volgograd; 2000. P. 116-23. 9. Kologorov A.I., Dmitrieva L.N., Shiyanova A.E., Tarasov M.A., Porshakov A.M., Popov N.V., Toporkov V.P., Toporkov A.V., Kutyrev V.V. [Epidemiologic Situation on Natural Focal and Zoonotic Infections in
Privolhzskiy Federal District in 2000-2009 and the Prognosis for 2010]. Probl. Osobo Opasn. Infek. 2010; (104): 5-10.

10. Korotkov V.B., Naumov A.V., Samoylova L.V. [Hemorrhagic Fever with Renal Syndrome in the Territory of the Saratov Region (Epidemiological Aspects)]. Saratov; 1996. 128 p.

11. Krasovskaya T.Yu., Shcherbakova S.A., Sharova I.N., Naydenova E.V., Bil Ko E.A., Chekashov V.N., Matrosov A.N., Yakovlev S.A., Porshakov A.M., Shilov M.M., Ryabova A.V., Knyazeva T.V., Mokrousova T.V. Fedorova Z.P., Kresova U.A., Talaeva E.A., Mironova N.I., Kutyrev V.V. Fedorova Z.P., Kresova U.A., Talaeva E.A., Mironova N.I., Kutyrev V.V.
[Studies of West Nile virus circulation in the territory of the Saratov region in 2010]. Probl. Osobo Opasn. Infek. 2011; (109): 13-7.

12. Kresova U.A., Kazakova L.V., Garanina S.B., Kozhanova O.I [Present-day tick-born infections in the territory of the Saratov region]. Infektsiya i Immunitet. 2012; 2(1-2): 160 .

13. Kutyrev I.V., Bil'ko E.A., Sharova I.N., Krasovskaya T.Yu., Chekashov V.N., Matrosov A.N. [Assessment of the role of mouse-like rodents background species in the preservation of Arboviral infections agents in the (97): 19-22.

14. Lukhnova L.Yu., Aikimbaev A.M., Pazylov E.K., Grazhdanov A.K., Solomadin M.B., Imankul S.I., Meka-Mechenko T.V., Nekrasova L.E [Epidemiological and epizootiological situation on anthax in the territory of the West-Kazakhstan region]. Dezinfektsiya. Antiseptika. 2012; 1(9):31-5

15. Tkachenko E.A., Dzagurova T.K., Nabatnikov P.A., Korotina N.A., Shevelev A.B., Sotskova S.E., Malkin A.E., Kiktenko A.V., Vorob'eva M.S., Mikhaylov M.I. [Construction of the vaccine against hemorrhagic fever with renal syndrome]. Infektsiya i Immunitet. 2012; 2(1-2):202.

16 . Fedorova Z.P., Korotkov V.B., Agafonova T.K., Barabanova A.V. [Concerning morbidity rate for tularemia infection in the territory of the Saratov region and current state of the natural foci]. Probl. Osobo Opasn. Saratov region and cur
Infek. 1993; 1-2:163-6.

17. Fedorova Z.P., Kozhanova O.I., Krasil'nikova N.N. [Pressing issues of level decline as regards health encounters among the population on the occasion of animal bites]. Infektsiya $i$ Immunitet. 2012; 2(1-2):206.

18. Shcherbakova S.A., Golovinskaya O.N., Klyueva E.V., Garanina S.B., Savitskaya L.V., Kulichenko A.N., Kutyrev V.V. [Results of blood sera testing obtained from the citizenry of the Saratov region for the presence of antibodies to Arboviruses]. Vopr. Virusol. 2002; 3:32-4.

19. Shcherbakova S.A., Bil'ko E.A., Klyueva E.V., Danilov A.N., Plotnikova E.A., Tarasov M.A., Chekashov V.N., Udovikov A.I. Knyazeva T.V., Shilov M.M., Samoylova L.V., Khramov V.N., Kazakova L.V., Kuklev E.V., Kulichenko A.N. [Ecology of arbovirus distribution in the territory of the Saratov region]. Zh. Mikrobiol. Epidemiol. Immunobiol. 2005; 5:27-30.

20. Shcherbakova S.A., Bil'ko E.A., Naidenova E.V., Krasovskaya T.Yu., Sharova I.N., Piontkovsky S.A., Utkin D.V., Chekashov V.N., Sludsky A.A., Popov N.V., Kuklev E.V., Firstov E.N., Potemina L.P., Logunova T.E. Vodina E.A., Kulichenko A.N., Kutyrev V.V. [Ecological and Epidemiological aspects of arbovirus circulation in the territory of the Saratov region]. In: [Arboviruses and Arboviral Infections]. M.; 2007. P. 150-2.

21. Shcherbakova S.A., Bil'ko E.A., Naidenova E.V., Kutyrev I.V., Krasovskaya T.Yu., Sludsky A.A., Knyazeva T.V., Matrosov A.N., Chekashov V.N., Sharova I.N., Samoylova L.V. [Detection of arbovirus antigens in ticks and mosquitoes, habitant in the territory of the Saratov region]. Med. Parazitol. Parazitarn. Bol. 2009; 2:38-41.

Authors:

Grazhdanov A.K., Toporkov A.V., Karnaukhov I.G., Popov N.V., Razdorsky A.S. Russian Research Anti-Plague Institute "Microbe" 46, Universitetskaya St., Saratov, 410005, Russian Federation. E-mail: rusrapi@ microbe.ru

Kozhanova O.I., Matveeva N.I., Arkhipova G.N. Rospotrebnadzor Administration in the Saratov Region. 7, Volskaya St., Saratov, 410028, Russian Federation. E-mail: sarrpn@san.ru

Ayazbaev T.Z. Uralsk Plague Control Station. 36/1, Chapaeva St., Uralsk, 090001, Republic of Kazakhstan. E-mail: pchum@mail.ru

Об авторах:

Гражданов А.К., Топорков А.В., Карнаухов И.Г., Попов Н.В., Раздорский А.C. Российский научно-исследовательский противочумный институт «Микроб». Российская Федерация, 410005, Саратов, ул. Университетская, 46. E-mail: rusrapi@microbe.ru

Кожанова О.И., Матвеева Н.И., Архипова Г.Н. Управление Роспотребнадзора по Саратовской области. Российская Федерация, 410028, Саратов, ул. Вольская, 7. E-mail: sarrpn@san.ru

Аязбаев Т. 3. Уральская противочумная станция. 090001,Республика Казахстан, Западно-Казахстанская область, г. Уральск, ул. Чапаева, 36/1. E-mail: pchum@mail.ru 